up automatic devices to meet the expediency of the moment could, if overdone, have dire results. For example, it is possible to place too much emphasis on the type of mathematics used for obtaining solutions by electronic computation. Numerical methods on a computer usually will provide an answer, when a function is not easily integrable by analysis or say, a troublesome differential equation has to be solved. With inadequate training in analytical mathematics, the scientist will shirk an attempt at explicit solution; he will resort to a solution with a computer. The result is found speedily, but lacks the sophistication of an explicit form. The functional form of solution might have suggested startling insight into the physical significance bearing on the problem. Use of a computer tends to block such discovery.

Lord Hailsham's exhortations concerning problems of living, the vital questions, need to be examined. It might be well if these could be treated by using 'human science', as he suggests. But unhappily (or happily) human emotions do not lend themselves readily to rational formation. They are frankly, but fascinatingly, inconsistent. "Nature is not bound. by reasonableness", as D. H. Wilkinson (professor of experimental physics at Oxford) has said. It is interesting to recall Lord Hailsham's presidential address to the Classical Association in Birmingham on April 13. There he stated that a solution to our modern perplexities, our aberrations in polities and morals, in æesthetics and philosophy probably lay in establishing again "the real validity of our moral and rsthetic value judgments symbolized in the classical culture in which we were steeped in our youth". This seems a better approach than "human science'.

As we plan to change curricula to satisfy the technological demands of our age, let us consider likely hazards to the nation. Without knowledge of nontechnological aspects of living, the adults of tomorrow will be vulnerable. They will be manipulated and beguiled. It was Stendhal who, in an article to the Paris Monthly Review*, June 1822, wrote rather provocatively, that a really useful 'science' a man can learn is the science of knowing the motives of men's actions. When you know these, you can try to cultivate in people other motives which will lead them to act in such a way as to bring about your own happiness. It does seem that men often lie when they speak of their motives. One must try to penetrate and undermine such untruths.

The art of knowing life is acquired by involvement with the full range of human passions. One must live. Always love and hatred will move men. Personal experience sometimes teaches. There are other sources. Our literature is rich in expression, "from the whispering of affection to the raging of madness" (Nietzsche). Not from the classics alone but from the genius of those with heightened sensibility in any age is the noble art of understanding human nature to be gleaned. It is likely to be withheld from those who persistently proffer their * Selected Journalism from the English Reviews by Stendhal, with
Translations of other Critical Writings, edit. by Strickland, G. (John Calder, London, 1959). punched programmes to our latter-day Oracle of Delphi, the computer. We need men of science who command savoir-vivre and who have a degree of empathy. How encouraging it is to read in The Times of June 28 that in the French baccalauréat examination, the entrée to universities there, respect is still shown for the irrational element. Even those candidates who plan to read science at the university might in their examinations be required to produce a dissertation on subjects such as: "What is the nature of æsthetic pleasure ?" or "Are we responsible for our passions?"

So let us not be carried away by excessive enthusiasm for the expediency of to-day, but be prepared for the demands of to-morrow. Then even while:

"Things fall apart; the centre cannot hold,

Mere anarchy is loosed upon the World.

The Blood-dimmed tide is loosed, and everywhere

The ceremony of innocence is drowned," (W. B. Yeats) we may have an abiding confidence to judge and judge wisely. For "a fool sees not the same tree as a wise man sees" (W. Blake).

\section{RESPIRATORY METABOLISM IN PLANTS}

\section{Respiratory Metabolism in Plants}

By Prof. Harry Beevers. (Row-Peterson Biological Monographs.) Pp. xi+232. Evanston, Ill.: Row, Peterson and Company, 1961.) 3.85 dollars.

THE title chosen for this book is meant to indicate that it does not attempt to cover the whole study of plant respiration, but is concerned only with the biochemistry of its reaction sequences. This is a rapidly developing field subject to annual inspection in various reviewing journals, but this is by no means to say that the present volume is supere. rogatory. It is not easy for the young student to pick the (more or less) permanent wheat from the ephemeral chaff in annual reviews. A considered statement of work from the past couple of decades is a sounder foundation, and nobody is better qualified to provide such a foundation at the present time than Prof. Beevers, who has himself made notable contributions to this work.

He has aimed at and succeeded in providing a factual statement of present knowledge with a minimum of controversy and 'interpretation' of dubious data. He covers the sequences and cycles of reactions during the production of pyruvate from glucose; the utilization of pyruvate in its various aspects, and oxidation systems and their constituent electron-transfers. These are treated at some length, and then there are briefer accounts of the energetics of respiration and the intracellular localization of respiratory enzymes.

The seventh chapter, on the regulation of respiratory-rates, seems to step a little outside the author's declared intention and to involve him rather more deeply in controversy. The remaining chapters deal with the relation of respiration to other physiological processes such as salt uptake, nitrogen metabolism, etc., and make interest $\mathrm{ng}$ reading.

The book has been well produced in paper-back form at a price which should not put it out of the reach of its most important customers and beneficiaries-biology students.
W. O. JAMES 